\title{
PENGELOLAAN KELAS OLEH GURU DALAM PEMBELAJARAN BAHASA JEPANG DI SMA NEGERI 1 TABANAN TAHUN PELAJARAN 2018/ 2019
}

\author{
Abdhiguna, K. A', G. S. Hermawan ${ }^{2}$, dan Mardani, D. M. $\mathrm{S}^{3}$ \\ ${ }^{123}$ Jurusan Pendidikan Bahasa Jepang, Universitas Pendidikan Ganesha, Singaraja,Bali \\ e-mail: aryama1206@gmail.com \\ satya.hermawan@undiksha.ac.id desakmardani@undiksha.ac.id
}

\begin{abstract}
Abstrak
Penelitian ini bertujuan untuk menganalisis bagaimana pengelolaan kelas yang dilakukan oleh guru dalam pembelajaran bahasa Jepang di SMA Negeri 1 Tabanan. Subjek dalam penelitian ini adalah guru bahasa Jepang di SMA Negeri 1 Tabanan. Pengumpulan data dilakukan dengan metode observasi, dokumentasi, wawancara, dan kemudian dianalisis menggunakan metode deskriptif kualitatif. Aktivitas analisis data dilakukan dengan mereduksi data, penyajian data, dan penarikan kesimpulan dan verifikasi. Hasil penelitian menunjukkan bahwa dalam mengelola kelas guru menggunakan pendekatan dalam pengelolaan kelas, prinsip-prinsip pengelolaan kelas, dan komponen-komponen keterampilan pengelolaan kelas untuk menciptakan dan memelihara kondisi belajar yang optimal. Komponen keterampilan pengelolaan kelas yang digunakan oleh guru dibagi menjadi dua bagian, yaitu keterampilan yang berhubungan dengan penciptaan dan pemeliharaan kondisi belajar yang optimal dan keterampilan yang berhubungan dengan pengembangan kondisi belajar yang optimal. Pendekatan resep dan prinsip keluwesan tidak dilakukan oleh guru.

\section{要旨}

本研究の目的は、タバナン第一公立高校で日本語を学ぶ際に教師がどのように教室を管理するか を分析することである。対象はタバナン第一国立高校の日本語教師である。データ収集は観察、 文書化、面接によって行われ、それから定性的記述法を用いて分析される。データ分析活動は、 データを減らし、データを提示し、そして結論と検証を引き出すことによって行われる。研究の 結果は、教室管理において、教師は教室管理アプローチ、教室管理の原則、および教室管理スキ ルの要素を使用して最適な学習条件を作成および維持することを示している。教師が使用する教 室管理スキルの要素は、二つの部分、すなわち最適な学習条件の作成と維持に関するスキルと最 適な学習条件の開発に関するスキルに分けられる。処方アプローチと柔軟性は、先生によって行 われない。

キーワード : アプローチ、原則、要素
\end{abstract}

\section{Pendahuluan}

Baik atau tidaknya kualitas suatu pendidikan akan dipengaruhi oleh berbagai faktor seperti faktor guru, siswa, ataupun dari sarana penunjang dalam proses pembelajaran. Namun, dari berbagai faktor tersebut guru merupakan salah satu faktor penentu bagi terciptanya suatu pendidikan yang berkualitas. Peran guru sangat penting dalam upaya tercapainya tujuan dari pendidikan itu sendiri. Dalam proses pembelajaran guru harus mampu menciptakan kondisi pembelajaran yang efektif, efisien, dan kondusif. Hal ini bukan suatu yang mudah dilakukan bahkan oleh guru yang sudah mempunyai pengalaman mengajar yang cukup lama sekalipun belum tentu dapat melakukannya. Dalam proses belajar mengajar berbagai macam permasalahan pasti akan ditemui. Baik permasalahan dari siswa, dari guru, maupun dari sarana yang menunjang proses pembelajaran. Karena di dalam kelas semua aspek pembelajaran saling terkait satu sama lain.

Upaya yang dapat dilakukan oleh guru dalam mengatasi permasalahan-permasalahan ini adalah dengan cara melakukan pengelolaan kelas dengan baik. Menurut Usman (2005:97) pengelolaan kelas adalah keterampilan guru untuk menciptakan dan memelihara kondisi 
belajar yang optimal dan mengembalikannya bila terjadi gangguan dalam proses belajar mengajar. Selanjutnya Djamarah \& Zain (2006:174) menjelaskan bahwa pengelolaan kelas dimaksudkan untuk menciptakan lingkungan belajar yang kondusif bagi anak didik sehingga tercapai tujuan pengajaran secara efektif dan efisien. Berikutnya Suyatno \& Djihad (2012:116) melihat pengelolaan kelas sebagai satu upaya yang dilakukan guru untuk mengkondisikan kelas dengan mengoptimalisasikan berbagai sumber (potensi yang ada pada diri guru, sarana dan lingkungan belajar di kelas) yang ditujukan agar proses belajar mengajar dapat berjalan sesuai dengan perencanaan dan tujuan yang ingin dicapai. Oleh karena itu keterampilan dalam mengelola kelas harus dikuasai dengan baik oleh guru.

Tetapi dalam kenyataannya masih banyak guru yang belum mampu mengelola kelas dengan baik. Berbagai macam permasalahan dalam dunia pendidikan hampir setiap hari kita dengar ataupun lihat melalui media massa khususnya permasalahan yang berhubungan dengan tingkah laku siswa seperti siswa mengejek guru, siswa menantang guru, siswa melakukan kekerasan fisik kepada guru ataupun sebaliknya guru melakukan hal yang sama kepada siswa karena melihat tingkah laku siswa yang tidak baik. Tentunya hal ini dapat dicegah ataupun dihindari jika guru dapat melakukan pengelolaan kelas dengan baik.

Pentingnya keterampilan mengelola kelas yang harus dikuasi oleh guru, menuntut guru untuk terus belajar dan berinovasi untuk menciptakan proses belajar mengajar yang menarik yang membuat siswa bergairah dalam belajar. Upaya guru dalam menciptakan dan memelihara kondisi pembelajaran yang optimal dan kondusif telah ditunjukkan oleh guru bahasa Jepang di SMA Negeri 1 Tabanan. Dari observasi awal yang telah dilakukan di kelas XI IPS 2 pada hari kamis tanggal 7 Februari 2019, guru dapat melakukan pengelolaan kelas dengan baik. Hal ini terlihat dari cara guru dalam memanfaatkan media pembelajaran yang telah disediakan oleh sekolah dengan baik. Dalam proses pembelajaran guru memanfaatkan LCD proyektor untuk menampilkan materi yang dipadukan dengan speaker kecil yang dibawa sendiri oleh guru untuk dipergunakan dalam materi menyimak. Hal ini menunjukkan antusias guru dalam melaksanakan proses pembelajaran.

Dalam proses pembelajaran guru dapat mencegah dan mengatasi masalah-masalah yang ditimbulkan oleh siswa dengan cara memberikan penguatan dan teguran ketika siswa menunjukkan tingkah laku yang kurang baik. Guru juga menunjukkan sikap tanggap dengan mendekati siswa ketika mengerjakan tugas yang diberikan dan mendekati siswa ketika siswa bertanya. Selain itu guru juga menunjukkan sikap hangat dengan tersenyum dan menunjukkan keakraban dengan siswa ketika bercakap-cakap dan membimbing siswa dalam proses pembelajaran. Dari observasi awal yang telah dilakukan, guru bahasa Jepang SMA Negeri 1 Tabanan sudah melakukan pengelolaan kelas dengan menerapkan pendekatan dalam pengelolaan kelas, prinsip-prinsip pengelolaan kelas, dan komponenkomponen keterampilan pengeloaan kelas.

Penelitian mengenai pengelolaan kelas pernah dilakukan oleh Riadi (2018). Hasil penelitian menunjukkan bahwa dalam mengelola kelas guru menggunakan berbagai pendekatan, prinsip-prinsip, dan komponen-komponen pengelolaan kelas. Pendekatan resep (cook book), keluwesan, penekanan pada hal-hal yang positif, dan menemukan serta memecahkan tingkah laku yang menimbulkan masalah tidak dilakukan oleh guru. Penataan ruang kelas dilakukan guru dengan cara disesuaikan dengan pembelajaran dan/atau atas seijin dari sekolah.

Mengacu dari hasil observasi yang telah dilakukan dan dari penelitian terdahulu yang telah dipaparkan, akan dilakukan penelitian lebih lanjut untuk mendapatkan hasil yang lebih detail mengenai bagaimana pengelolaan kelas yang dilakukan oleh guru bahasa Jepang di SMA Negeri 1 Tabanan dengan fokus variabel penelitian yaitu, pendekatan dalam pengelolaan kelas, prinsip-prinsip pengelolaan kelas, dan komponen-komponen keterampilan pengelolaan kelas.

Alasan penelitian ini dilakukan di SMA Negeri 1 Tabanan karena dari observasi awal yang telah dilakukan dalam proses pembelajaran khususnya dalam mengelola kelas, guru sudah dapat melakukannya dengan baik. Pemberian penguatan dan teguran dilakukan dengan segera oleh guru ketika siswa menunjukkan tingkah laku yang tidak baik sehingga dapat mencegah meluasnya penyimpangan tingkah laku. Dalam mengajar guru juga menunjukkan 
sikap hangat yang akan dapat menciptakan iklim sosial yang positif di dalam kelas yang juga akan dapat mengurangi kemungkinan menculnya permasalahan tingkah laku dari siswa. Dengan keterampilan pengelolaan kelas yang ditunjukkan oleh guru, berbagai permasalahan yang ditimbulkan oleh siswa akan dapat diatasi.

Penelitian ini hanya akan membahas mengenai pendekatan dalam pengelolaan kelas, prinsip-prinsip pengelolaan kelas, dan komponen-komponen keterampilan pengelolaan kelas yang dilakukan oleh guru sebagai upaya untuk menciptakan proses belajar mengajar yang efektif, efisien, dan kondusif dalam pembelajaran bahasa Jepang di SMA Negeri 1 Tabanan. Rumusan masalah dalam penelitian ini adalah, bagaimanakah pengelolaan kelas yang dilakukan oleh guru di SMA Negeri 1 Tabanan dalam pembelajaran bahasa Jepang?

Berdasarkan rumusan masalah tersebut, tujuan penelitian ini adalah untuk menganalisis pengelolaan kelas yang dilakukan oleh guru dalam pembelajaran bahasa Jepang di SMA Negeri 1 Tabanan

\section{Metode}

Penelitian ini menggunakan rancangan penelitian deskriptif kualitatif. Alasan rancangan ini digunakan karena data yang dikumpulkan adalah berupa kata-kata, gambar, dan bukan angka-angka (Moleong, 2006:11).

Metode pengumpulan data yang digunakan dalam penelitian ini adalah metode observasi, wawancara, dan dokumentasi.

Dalam penelitian ini sumber data berupa kata-kata dan tindakan didapatkan melalui observasi dan wawancara dengan guru mengenai pengelolaan kelas yang dilakukan guru dalam pembelajaran bahasa Jepang. Sedangkan dokumentasi berupa foto dan Rencana Pelaksanaan Pembelajaran (RPP) digunakan sebagai penguat dan pelengkap dari data yang akan dianalisis.

Teknik analisis data yang digunakan dalam penelitian ini adalah teknik analisis Miles dan Huberman. Miles and Huberman (dalam Sugiyono, 2009:246) mengemukakan bahwa aktivitas dalam analisis data kualitatif dilakukan secara terus menerus sampai tuntas, sehingga datanya sudah jenuh. Aktivitas dalam analisis data, yaitu data reduction, data display, dan conclusion drawing/verifying.

Dalam penelitian ini uji kredibilitas dilakukan dengan menggunakan triangulasi Teknik. Triangulasi teknik untuk menguji kredibilitas data dilakukan dengan cara mengecek data kepada sumber yang sama dengan teknik yang berbeda. Misalnya data diperoleh dengan wawancara, lalu dicek dengan observasi, dokumentasi, atau kuesioner.

Bila dengan tiga teknik pengujian kredibilitas data tersebut, menghasilkan data yang berbeda-beda, maka peneliti melakukan diskusi lebih lanjut kepada sumber data yang bersangkutan atau yang lain, untuk memastikan data mana yang dianggap benar. Atau mungkin semuanya benar, karena sudut pandangnya berbeda-beda (Sugiyono, 2009:274).

\section{Hasil dan Pembahasan}

Hasil penelitian menunjukkan bahwa dalam mengelola kelas guru bahasa Jepang di SMA Negeri 1 Tabanan menerapkan pendekatan dalam pengelolaan kelas, prinsip-prinsip pengelolaan kelas, dan komponen-komponen keterampilan pengelolaan kelas.

Pendekatan-pendekatan yang digunakan oleh guru dalam mengelola kelas antara lain, pendekatan kekuasaan, pendekatan ancaman, pendekatan kebebasan, pendekatan pengajaran, pendekatan perubahan tingkah laku, pendekatan suasana emosi dan hubungan sosial, pendekatan proses kelompok, dan pendekatan elektis atau pluralistik.

Pendekatan kekuasaan ditunjukkan oleh guru ketika mendisplinkan siswa dan mengendalikan tingkah laku siswa dalam proses pembelajaran. Untuk memusatkan kembali perhatian siswa terhadap proses pembelajaran guru melakukan pendekatan kekuasaan dengan berkata "coba yang lainnya perhatikan ya.", "yang lain perhatikan ya.". Ketika guru melihat salah satu siswa yang memainkan handphone-nya ketika guru sedang menjelaskan materi pelajaran, guru melakukan pendekatan kekuasaan dengan berkata "Asoka hp-nya dimasukkan dulu." 
Pendekatan ancaman dilakukan oleh guru ketika mendisplinkan dua orang siswa yang tidak kunjung beranjak dari tempat duduknya pada waktu pembentukan kelompok guru memberikan ancaman dengan berkata "saya hitung sampai tiga beranjak dari tempat duduk. Satu...dua...tiga. Kalau tidak dihitung kalian tidak akan cepat ya."

Dalam pendekatan kebebasan guru mengusahakan kebebasan anak didik dalam mengerjakan sesuatu dalam upaya untuk memperlancar tugas-tugas ataupun untuk memberikan kemudahan bagi anak didik dalam belajar. Guru memberikan kebebasan kepada siswa untuk mencari informasi terkait dengan materi pelajaran dari mana saja. Seperti ketika guru memperbolehkan siswa mengakses internet melalui smartphone yang dibawanya untuk mencari contoh kosakata mengenai gambaran fisik atau sifat seseorang.

Dalam pendekatan pengajaran guru sudah merencanakan dan mengimplementasikan pelajaran yang baik. Dimana sebelum melaksanakan proses pembelajaran guru sudah mempersiapkan RPP terlebih dahulu. guru sudah mempersiapkan alat atau media dan bahan yang akan digunakan untuk menyampaikan materi pelajaran. Dalam proses pembelajaran guru terlihat siap dalam melaksanakan tugasnya. Baik dalam menggunakan dan memanfaatkan alat dan bahan-bahan yang telah disiapkan, dalam menyampaiakan materi pelajaran, maupun dalam membimbing siswa yang mengalami kesulitan. Guru juga mampu mempertahankan suasana kelas yang tertib dan disiplin dengan mengawasi dan menegur siswa ketika siswa melakukan kesalahan.

Dalam pendekatan perubahan tingkah laku, guru mengembangkan tingkah laku siswa yang baik dengan memberikan penguatan positif dan mencegah tingkah laku siswa yang kurang baik dengan memberikan penguatan negatif. Penguatan positif diberikan guru dengan berkata "oke sudah bagus ya." ketika siswa dapat menyebutkan gambaran fisik atau sifat dari seseorang pada gambar di buku pelajaran dengan benar. Penguatan negatif diberikan oleh guru ketika menegur siswa yang ribut dalam proses pembelajaran dengan berkata "oke kalau ada yang berbicara sebaiknya...didengarkan.", "yang lainnya kerjakan dulu ya jangan ribut."

Dalam pendekatan suasana emosi dan hubungan sosial, guru menciptakan iklim atau suasana emosional dan hubungan sosial yang positif dalam kelas. Sebelum memulai pelajaran guru mengucapkan salam dan menanyakan kabar siswa terlebih dahulu dengan berkata "Minasan ohayou gozaimasu.", "Ogenki desuka." Dengan mengucap salam dan menanyakan kabar siswa, guru menunjukkan kepedulian dan sikap hangat yang akan dapat menciptakan iklim yang positif di dalam kelas. Dalam mengajar guru tersenyum, dan menunjukkan keakraban dengan siswa ketika bercakap-cakap dan ketika membimbing siswa yang mengalami kesulitan dalam proses pembelajaran.

Pada pendekatan proses kelompok guru mengelompokkan siswa ke dalam enam kelompok kecil yang beranggotakan 4-5 orang siswa. Dalam usaha guru agar perkembangan dan pelaksanaan proses kelompok berjalan dengan efektif dan produktif, guru mengawasi kegiatan diskusi siswa dan membantu siswa ketika mengalami kesulitan.

Dalam pendekatan elektis atau pluralistik guru menggunakan berbagai macam pendekatan pengelolaan kelas dalam berbagai situasi. Adapun pendekata-pendekatan tersebut seperti yang sudah dipaparkan pada pembahasan pendekatan pengelolaan kelas sebelumnya antara lain, pendekatan kekuasaan, pendekatan ancaman, pendekatan kebebasan, pendekatan pengajaran, pendekatan perubahan tingkah laku, pendekatan suasana emosi dan hubungan sosial, dan pendekatan proses kelompok. Selain menggunakan salah satu pendekatan pada situasi tertentu, guru juga mengkombinasikan pendekatan tersebut. Seperti ketika guru memperbolehkan siswa untuk mencari informasi yang berkaitan dengan materi pelajaran dari mana saja termasuk dari media internet dengan menggunakan smartphone yang dibawanya, guru memberlakukan peraturan-peraturan tertentu dengan menginstruksikan siswa untuk memasukkan smartphone-nya kembali setelah siswa menemukan dan selesai mencatat informasi yang didapatnya. Sehingga ketika guru melanjutkan menjelaskan materi pelajaran, perhatian siswa tidak akan terganggu. Dalam hal ini guru mengkombinasikan pendekatan kebebasan dengan pendekatan kekuasaan. 
Dalam mengelola kelas guru juga menggunakan prinsip-prinsip pengelolaan kelas yang meliputi hangat dan antusias, tantangan, bervariasi, penekanan pada hal-hal yang positif, dan penanaman disiplin diri.

Sikap hangat ditunjukkan oleh guru dengan tersenyum ketika melihat salah satu siswa menunjukkan perkembangan yang baik dalam kegiatan kelompok. Sikap hangat guru juga terlihat ketika guru bercakap-cakap dan membimbing siswa dalam proses pembelajaran. Guru akrab dengan siswa dan sesekali siswa tersenyum dan tertawa kecil ketika bercakapcakap dengan guru. Keantusiasan guru dalam proses pembelajaran terlihat ketika guru mencontohkan dan memperagakan cara memperkenalkan dan menceritakan tentang anggota keluarga atau orang terdekat bagi siswa.melalui media foto yang akan digunakan oleh siswa. Guru tersenyum dan terlihat aktif ketika memberikan contoh kepada siswa.

Dalam upaya untuk menciptakan proses belajar mengajar yang menantang, guru menggunakan kata-kata, cara kerja, bahan-bahan, dan memanfaatkan media pembelajaran yang dapat menantang gairah belajar siswa. Kata-kata menantang digunakan guru ketika meminta siswa untuk menjawab soal latihan menyimak yang diberikan dengan berkata "oke sebelum saya tunjuk untuk nomor satu siapa yang mau?", "nomor dua... ada yang mau? sebelum saya tunjuk." Cara kerja menantang dilakukan oleh guru ketika meminta siswa untuk mewawancarai temannya mengenai sarapan paginya, dan guru menginstruksikan siswa untuk menggunakan bahasa Jepang dengan berkata "nihongo de itte kudasai".

Dalam memanfaatkan media dan bahan yang dapat menantang gairah siswa dalam belajar, guru menggunakan media power point untuk menampilkan materi pelajaran dan gambar dan juga sebagai media bantu dalam memfasilitasi siswa ketika latihan menyimak.

Dalam prinsip bervariasi guru menggunakan alat atau media, gaya mengajar, dan pola interaksi yang bervariasi untuk menghindarkan siswa dari rasa jenuh dan meningkatkan perhatian siswa dalam proses pembelajaran.

Dalam proses pembelajaran guru sudah menggunakan alat atau media pembelajaran yang bervariasi. Guru memanfaatkan LCD proyektor yang digunakan untuk menampilkan gambar dan materi pelajaran pada slide power point dan juga sebagai media bantu dalam latihan menyimak. Guru juga menggunakan papan tulis untuk memperjelas penekanan pada hal-hal yang penting terkait dengan materi pelajaran.

Selain menggunakan alat atau media pembelajaran yang bervariasi, guru juga menggunakan variasi gaya mengajar. Seperti variasi suara, variasi gerakan anggota badan dan mimik, dan variasi perpindahan posisi guru dalam kelas.

Adapun variasi suara yang guru gunakan yaitu, guru menggunakan volume suara yang cukup keras ketika memberikan siswa pengarahan sebelum mengerjakan tugas yang diberikan, guru menggunakan volume suara kecil ketika menegur salah satu kelompok belajar siswa yang mengobrol di luar konteks pelajaran saat kegiatan diskusi berlangsung, guru menggunakan nada suara rendah ketika menegur siswa yang tidak membawa buku pelajaran.

Variasi gerakan anggota badan dilakukan oleh guru ketika menunjuk siswa untuk mempresentasikan hasil laporannya, mengangguk ketika menanggapi pertanyaan dari siswa, mendekatkan telunjuknya ke bibir ketika meminta atau mengisyaratkan siswa untuk tidak ribut ketika mendengarkan presentasi dari temannya. Sedangkan variasi mimik ditunjukkan oleh guru dengan mendelik, tersenyum sambil mengeleng-gelengkan kepalanya, mengangkat alisnya, tersenyum dan sedikit tertawa ketika mendengarkan pernyataan dari siswa tentang gambaran fisik dari anggota keluarganya.

Ketika mengajar guru melakukan variasi perpindahan posisi dalam kelas. Ketika menjelaskan materi pelajaran, guru berpindah posisi dari kiri ke kanan atau sebaliknya. Guru bergerak dari depan ke belakang dari samping kiri ke kanan untuk mengontrol dan mengawasi kegiatan siswa.

Pola interaksi yang bervariasi dilakukan oleh guru dengan bertanya kepada siswa secara keseluruhan dan kepada siswa secara individual.

Penekanan pada hal positif dilakukan guru ketika memberikan apresiasi dengan bertepuk tangan bersama siswa, setelah semua kelompok belajar siswa selesai menyampaikan hasil laporannya mengenai survei sarapan pagi. 
Dalam prinsip penanaman disiplin diri, kedisiplinan ditunjukkan oleh guru ketika memulai dan mengakhiri proses belajar mengajar sesuai dengan waktu yang telah ditentukan dan guru berpakaian dan berpenampilan rapi dalam menjalankan tugasnya.

Dalam mengelola kelas guru juga menggunakan komponen-komponen keterampilan pengelolaan kelas yang dibagi menjadi dua bagian, yaitu keterampilan yang berhubungan dengan penciptaan dan pemeliharaan kondisi belajar yang optimal dan keterampilan yang berhubungan dengan pengembangan kondisi belajar yang optimal.

Keterampilan yang berhubungan dengan penciptaan dan pemeliharaan kondisi belajar yang optimal yang dilakukan oleh guru meliputi sikap tanggap, membagi perhatian, dan pemusatan perhatian kelompok.

Sikap tanggap ditunjukkan oleh guru dengan cara melakukan kontak pandang dengan siswa ketika menjelaskan materi pelajaran, mendekati masing-masing kelompok belajar siswa ketika kegiatan diskusi berlangsung, memberikan pernyataan berupa tanggapan atau komentar terhadap sesuatu yang dikemukakan oleh siswa, dan memberi reaksi terhadap gangguan dan ketakacuhan siswa seperti ketika guru melihat salah satu siswa yang memainkan handphone-nya saat guru sedang menjelaskan materi pelajaran, guru menegur siswa tersebut dengan berkata "Asoka hp-nya dimasukkan dulu."

Membagi perhatian secara visual ditunjukkan guru ketika memberikan pertanyaan kepada salah satu siswa dan menunggu siswa tersebut untuk menjawab dengan memusatkan perhatian kepada siswa tersebut. Kemudian guru mengalihkan pandangannya dengan melirik siswa lainnya yang meminta izin untuk pergi ke toilet. Membagi perhatian secara verbal dilakukan guru ketika memberi izin siswa yang datang dari toilet untuk masuk ke dalam kelas dengan mengangguk dan berkata "hal" sementara guru sedang menjelaskan pola kalimat mengenai gambaran fisik dan sifat kepada siswa lainnya.

Untuk memusatkan perhatian siswa dalam kegiata kelompok, guru berkeliling kelas dan mendekati masing-masing kelompok belajar siswa, mengawasi kegiatan diskusi siswa, dan memberikan teguran kepada salah satu kelompok belajar siswa yang mengobrol di luar konteks pelajaran.

Keterampilan yang berhubungan dengan pengembangan kondisi belajar yang optimal yang dilakukan oleh guru meliputi strategi modifikasi tingkah laku, pendekatan pemecahan masalah kelompok, dan menemukan dan memecahkan tingkah laku yang menimbulkan masalah.

Modifikasi tingkah laku dilakukan guru ketika memperingati dan menegur siswa untuk tidak mencorat-coret buku paket yang digunakan dengan memberikan penguatan negatif.

Dalam pendekatan pemecahan masalah kelompok, guru memberikan bimbingan kepada salah satu kelompok belajar siswa yang kebingungan ketika kegiatan diskusi berlangsung. Guru memperlancar tugas mereka dengan ikut terlibat dalam kegiatan diskusi.

Dalam strategi menemukan dan memecahkan tingkah laku yang menimbulkan masalah, guru menemukan dan dapat memecahkan masalah yang ditumbulkan oleh salah satu siswa yang menunjukkan ketakacuhan atau ketidakpedulian dalam mengikuti proses pembelajaran.

\section{Simpulan dan Saran}

Kesimpulan yang dapat diambil dari penelitian ini adalah, guru bahasa Jepang di SMA Negeri 1 Tabanan melakukan pengelolaan kelas dalam pembelajaran bahasa Jepang dengan menerapkan pendekatan dalam pengelolaan kelas yang meliputi pendekatan kekuasaan, pendekatan ancaman, pendekatan kebebasan, pendekatan pengajaran, pendekatan perubahan tingkah laku, pendekatan suasana emosi dan hubungan sosial, dan pendekatan elektis atau pulralistik. Sedangkan pendekatan resep yaitu pendekatan yang dimana guru membuat dan membawa satu daftar yang menggambarkan tentang yang harus dan yang tidak boleh dikerjakan oleh guru dalam mereaksi semua masalah atau situasi yang terjadi di kelas tidak dilakukan oleh guru karena dalam mereaksi setiap masalah, guru menyesuaikannya dengan situasi yang terjadi pada saat itu. 
Dalam mengelola kelas guru juga mengunakan prinsip-prinsip pengelolaan kelas yang meliputi hangat dan antusias, tantangan, bervariasi, penekanan pada hal-hal yang positif, dan penanaman disiplin diri. Sedangkan prinsip keluwesan yang dimana guru mengubah strategi mengajarnya ketika proses pembelajaran berlangsung tidak dilakukan oleh guru karena sebelum melaksanakan proses pembelajaran guru sudah mempersiapkan strategi yang akan digunakan dalam mengajar dan ketika melaksanakan proses pembelajaran strategi mengajar yang digunakan sudah sesuai dengan keinginan guru.

Komponen-komponen keterampilan pengelolaan kelas yang berhubungan dengan penciptaan dan pemeliharaan kondisi belajar yang optimal dilakukan oleh guru dengan cara menunjukkan sikap tanggap dengan melakukan kontak pandang, gerak mendekati, memberi pernyataan, dan memberi reaksi terhadap gangguan dan ketakacuhan siswa. Dengan cara membagi perhatian baik secara visual maupun verbal dan dengan cara pemusatan perhatian kelompok. Dan komponen-komponen keterampilan pengelolaan kelas yang berhubungan dengan pengembangan kondisi belajar yang optimal dilakukan oleh guru dengan cara modifikasi tingkah laku, pendekatan pemecahan masalah kelompok, memperlancar tugastugas dan mengusahakan terjadinya kerjasama yang baik dalam pelaksanaan tugas, dan dengan cara menemukan dan memecahkan tingkah laku yang menimbulkan masalah.

Berdasarkan hasil penelitian yang telah dilakukan, saran akan ditujukan kepada guru dan kepada peneliti lainnya yang akan melakukan penelitian sejenis. Bagi guru dalam mengelola kelas pemberian penguatan negatif untuk mencegah ataupun menghentikan tingkah laku siswa yang menimbulkan masalah memang perlu untuk dilakukan tetapi pemberian penguatan positif tidak kalah pentingnya untuk menciptakan proses pembelajaran yang dapat mengembangkan tingkah laku baik siswa. Oleh karena itu sebaiknya guru lebih banyak menggunakan penguatan positif untuk mengembangkan tingkah laku baik siswa. Penguatan positif berupa pernyataan dapat diberikan guru ketika siswa dapat menjawab pertanyaan yang diberikan dengan benar, ketika siswa dapat mengerjakan tugas yang diberikan dengan baik, ataupun ketika siswa menunjukkan perilaku yang baik dalam proses pembelajaran.

Bagi peneliti lainnya yang akan melakukan penelitian sejenis, diharapkan menambahkan pembahasan mengenai kendala-kendala yang dihadapi oleh guru dalam mengelola kelas. Untuk mengetahui kendala-kendala yang dihadapi oleh guru dalam mengelola kelas, dapat dilakukan dengan cara melakukan wawancara mendalam dengan guru.

\section{Daftar Pustaka}

Djamarah, Syaiful Bahri dan Aswan Zain. 2006. Strategi Belajar Mengajar. Jakarta: PT Rineka Cipta.

Moleong, j, Lexy. 2006. Metodologi Penelitian Kualitatif. Bandung: PT. Remaja Rosdakarya.

Riadi, Riyan. Sadnyana., dan Sri Mardani. 2018. "Pengelolaan Kelas Dalam Pembelajaran Bahasa Jepang Oleh Guru Bahasa Jepang SMA Negeri 2 Singaraja". Tersedia pada https://ejournal.undiksha.ac.id/index.php/JJPBJ/article/view/14953 (diakses pada tanggal 7 April 2019)

Sugiyono. 2009. Metode Penelitian Kuantitatif Kualitatif dan R\&D. Bandung: CV. ALFABETA. Suyanto dan Asep Djihad. 2012. Bagaimana Menjadi Calon Guru dan Guru Profesional. Cetakan Ke-1. Yogyakarta: Multi Pressindo.

Usman,Uzer. 2005. Menjadi Guru Profesional. Bandung: PT Remaja Rosdakarya. 